\title{
MEMBANGUN MANAJEMEN KEBERAGAMAN MELALUI AKULTURASI BUDAYA KERJA KARYAWAN EKSPATRIAT DAN KARYAWAN LOKAL
}

\author{
Oktadwilaras Anugerah Putri Papuling $^{1^{*}}$, Agus Sugiarto ${ }^{1}$ \\ ${ }^{1}$ Universitas Kristen Satya Wacana Salatiga, Indonesia \\ *e-mail: oktadwilaras@gmail.com
}

\begin{abstract}
Abstrak
Keberagaman merupakan salah satu hal yang penting dan berdampak pada kinerja suatu organisasi, oleh karena itu keberagaman perlu dikelola dengan baik melalui pengelolaan keberagaman. Salah satu bagian dari keberagaman adalah budaya. Perbedaan budaya dan bahasa akan menimbulkan berbagai bentuk hambatan akulturasi. Beberapa penelitian sebelumnya telah membahas tentang akulturasi tetapi dalam konteks sosial, sedangkan penelitian tentang akulturasi dalam konteks budaya kerja masih terbatas. Tujuan penelitian ini untuk menganalisis bentuk, proses, dampak dan hambatan pengelolaan keberagaman melalui akulturasi dalam konteks budaya kerja karyawan ekspatriat dan karyawan lokal di PT NHM. Penelitian ini merupakan penelitian eksploratif dengan pendekatan kualitatif, menggunakan lima orang karyawan aktif yang bekerja di PT NHM sebagai narasumber. Hasil penelitian menunjukkan bahwa PT NHM berhasil mengelola keberagaman melalui akulturasi budaya kerja dengan baik. Hal ini dapat dilihat melalui proses akulturasi yang berlangsung di PT NHM dan banyak memberikan dampak positif bagi karyawan.
\end{abstract}

Kata kunci: Keberagaman; Manajemen Keberagaman; Akulturasi; Budaya Kerja

\begin{abstract}
Diversity is one of the essential things and impacts the performance of an organization. Therefore, diversity needs to be appropriately managed through diversity management. One part of diversity is culture. Differences in culture and language will cause various forms of acculturation barriers. Several previous studies have discussed acculturation but in a social context, while research on acculturation in work culture is still limited. The purpose of this study was to determine the form, process, impacts, and barriers of diversity management through acculturation in the context of the work culture of expatriate employees and local employees at PT NHM. This research is exploratory research with a qualitative approach, using five active employees who work at PT NHM as resource persons. The results showed that PT NHM managed to manage diversity through the acculturation of work culture well. This can be seen through the acculturation process that took place at PT NHM and has had a positive impact on employees.
\end{abstract}

Keywords: Diversity; Diversity Management; Acculturation; Work Culture

This is an open access article under the CC BY-SA license.

Copyright (C) 2021 by Author. Published by Universitas Pendidikan Ganesha.

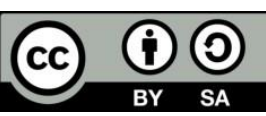


Oktadwilaras Anugerah Putri Papuling, Agus Sugiarto | Membangun Manajemen Keberagaman Melalui Akulturasi Budaya Kerja Karyawan Ekspatriat Dan Karyawan Lokal

\section{PENDAHULUAN}

Praktik pengelolaan sumber daya manusia (SDM) erat kaitannya dengan lingkungan sosial budaya, ekonomi, politik, dan hukum bangsa. Berbagai dimensi lingkungan berdampak pada terjadinya keberagaman sumber daya manusia dalam organisasi. Nguyen \& Velayutham (2018) mengemukakan pertemuan lintas budaya yang tidak disengaja adalah aspek hidup dengan perbedaan budaya yang dapat menghasilkan ketidaknyamanan, ketegangan dan konflik di tempat kerja. Wentling \& Palma-Rivas (1997) membagi keberagaman menjadi empat tingkatan yaitu: (1) keberagaman sebagai suatu keseimbangan ras/etnis/seksual, (2) keberagaman dijadikan sebagai suatu pemahaman tentang budaya lain, (3) keberagaman dianggap memiliki nilai-nilai budaya yang berbeda, dan (4) keberagaman sebagai sesuatu yang luas yang meliputi bidang budaya, subkultur, dan individu.

Tantangan keberagaman terutama dalam hal interaksi antara budaya yang berbeda di seluruh industri. Pourjam (2020) menyebutkan bahwa kinerja organisasi dipengaruhi oleh tingkat keberagaman di tempat kerja, karena keberagaman menjadi salah satu hal yang berdampak pada kinerja organisasi, maka keberagaman perlu dikelola dengan baik. Pengelolaan keberagaman dilakukan melalui manajemen keberagaman. Hal senada disampaikan oleh Farmanesh et al. (2020) bahwa keberagaman tenaga kerja memiliki hubungan yang signifikan dengan kinerja secara keseluruhan. Penelitian Flory et al. (2021) juga menunjukkan bahwa sinyal yang menilai keberagaman tempat kerja memiliki implikasi penting untuk dampak secara jelas pada ukuran dan komposisi demografis kumpulan pelamar, dan lebih umum lagi bagi pencari kerja yang menuju karir profil tinggi. Singha \& Sivarethinamohan (2021) juga mengemukakan bahwa tenaga kerja yang beragam membawa nilai tinggi, reputasi yang baik, dan peningkatan produktivitas bagi organisasi. Secara umum manajemen keberagaman dapat dipahami sebagai suatu tahapan proses manajerial dengan cakupan yang luas yang bertujuan untuk menciptakan lingkungan kerja bagi karyawan, dan mendorong pimpinan dalam menciptakan karyawan yang aktif, lebih berdaya saing dan mempengaruhi karyawan untuk dapat memaksimalkan potensi diri. Melalui penelitiannya $\mathrm{Ng}$ \& Sears (2020) mengemukakan bahwa agar praktik keberagaman dapat diterapkan, CEO pertama-tama harus memahami nilai peningkatan keberagaman di tempat kerja dan membentuk keyakinan positif tentang keberagaman tenaga kerja. Meskipun banyak CEO yang mendukung manajemen keberagaman, keyakinan ini sering tidak diterjemahkan ke dalam kebijakan dan praktik organisasi yang nyata karena manajer SDM menghadapi tuntutan organisasi yang beragam dan bersaing selain mengelola keberagaman. Manajemen 
Oktadwilaras Anugerah Putri Papuling, Agus Sugiarto | Membangun Manajemen Keberagaman Melalui Akulturasi Budaya Kerja Karyawan Ekspatriat Dan Karyawan Lokal

keberagaman dianggap sebagai bagian dari manajemen sumber daya manusia dan diterapkan untuk secara berkelanjutan dan efisien menggunakan keberagaman tenaga kerja suatu organisasi. Dengan demikian, upaya dilakukan untuk menggunakan aspek positif dari keberagaman untuk keberhasilan jangka panjang suatu perusahaan (Kraus et al., 2019). Salah satu dimensi dalam keberagaman adalah keberagaman budaya.

Budaya adalah suatu sistem yang meliputi bahasa, benda, seni musik yang dipercayai dan kegiatan kemasyarakatan yang bermakna kebersamaan dan berhubungan satu sama lain (Yunus, 2013). Setiap daerah bahkan individu memiliki kepercayaan, norma, nilai serta perilaku yang berbeda yang sesuai dengan budaya yang dianutnya. Perbedaan tersebut akan menjadi hambatan untuk terjadinya akulturasi. Akulturasi merupakan suatu proses di lingkungan sosial masyarakat di mana didalamnya terjadi hubungan antar dua budaya yang berbeda yang mengakibatkan terciptanya budaya baru tanpa menghilangkan unsur dari budaya asli. Berry (2005) menyatakan akulturasi adalah proses di mana terjadinya perubahan budaya secara psikologis, hal ini terjadi karena kontak antara dua atau lebih kelompok. Kontak budaya atau lebih sering disebut akulturasi budaya adalah suatu penggabungan dua atau lebih budaya yang karakter budayanya saling berhubungan (Anakotta et al., 2019). Akulturasi dapat dilihat sebagai bagian dari cakupan yang lebih luas mengenai masalah perubahan budaya. Pada tingkatan individu, seorang individu harus mempertimbangkan perubahanpsikologis yang terjadi serta memiliki pengaruh dalam penyesuaian pada keadaan yang baru. Perubahan tersebut dapat menciptakan rangkaian perubahan yang dapat dengan mudah diselesaikan, misalnya cara berkomunikasi, berpakaian atau cara makan. Selain itu, juga dapat menjadi suatu bentuk masalah yang mengakibatkan stress akulturatif dalam bentuk ketidakpastian, cemas dan depresi (Berry, 2005 dalam Mu, 2019). Akulturasi kebudayaan yang dapat diterima dan dipakai dalam masyarakat Indonesia meliputi bahasa, religi/kepercayaan, organisasi sosial kemasyarakatan, kesenian dan pengetahuan. Melalui kebudayaan, individu belajar berbagai hal yang dimulai dari penggunaan bahasa, membangun hubungan dan pertemanan (Koetjaraningrat, 2005 dalam Firmansyah, 2016). Karena akulturasi merupakan turunan langsung dari budaya, maka masuk akal untuk mendefinisikan akulturasi sebagai perubahan nilai sebagai respons terhadap kontak dengan budaya lain (Taras et al., 2013).

Manusia tidak bisa menghindar dari kehidupan sosial, kehidupan tersebut ditunjang oleh komunikasi dan komunikasi adalah hal yang sangat penting, komunikasi berhubungan dengan individu-individu lainnya dan setiap individu membutuhkan hubungan sosial dengan orang lain melalui pertukaran informasi yang menjadi 
Oktadwilaras Anugerah Putri Papuling, Agus Sugiarto | Membangun Manajemen Keberagaman Melalui Akulturasi Budaya Kerja Karyawan Ekspatriat Dan Karyawan Lokal

penengah untuk menyatukan manusia. Informasi hadir melalui perilaku manusia (Mulyanan \& Rakhmat, 2006 dalam Han \& Goleman,2019).Teori komunikasi ini perlu dipakai karena merupakan dasar terjadinya komunikasi antar budaya (Liliweri , 2001 dalam Muzakkir \& Fadhlain, 2019).

Terdapat tiga masalah yang diidentifikasi sebagai faktor yang memengaruhi terjadinya akulturasi diantaranya; Kontak yang terpenting dalam akulturasi dan merupakan perpaduan antara dua kelompok budaya atau individu yang secara bersama atau melakukan kontak secara tidak langsung. Selanjutnya pengaruh timbal balik, kedua kelompok saling mempengaruhi. Faktor berikut, adanya perubahan mencakup proses yang berubah-ubah dan hasil yang dicapai relatif stabil artinya dalam akulturasi dapat kita lihat bagaimana proses perubahan terjadi (Taras et al., 2013).Komunikasi antar budaya ialah komunikasi antar individu yang berlansung antar anggota kebudayaan yang berbeda (Liliweri, 2001 dalam Muzakkir \& Fadhlain, 2019). Faktor budaya, sosio-budaya, psikobudaya serta faktor lingkungan merupakan faktor-faktor yang berpengaruh pada komunikasi antar budaya. Faktor-faktor tersebut memerlukan suatu adaptasi agar dapat menyesuaikan diri. Istilah akulturasi sering digunakan oleh para ahli sebagai rujukan penyesuaian individu pada suatu budaya yang baru.

Penelitian sebelumnya menjelaskan bahwa pengaruh budaya Tionghoa yang nyata dalam kehidupan bermasyarakat terdapat kesamaan budaya yang dipraktikkan etnis Tionghoa dengan masyarakat Aceh di wilayah barat selatan, antara lain budaya perkawinan, perayaan hari raya, budaya peusijueuk (menepung tawar), kedua etnis tersebut dapat menyerap nilai-nilai baru antara kebudayaan melalui proses akulturasi (Muzakkir \& Fadhlain, 2019). Penelitian lain menunjukkan terdapat pengaruh signifikan antara komunikasi personal dan sosial dalam proses interaksi antar budaya terhadap kesadaran bahasa daerah dan tidak ada pengaruh lingkungan komunikasi serta potensi akulturasi menuju budaya bahasa daerah antara siswa Sulawesi Selatan di Bandung (Fitriana et al., 2018). Beberapa penelitian terkait dengan keberagaman dan akulturasi budaya di tempat kerja dilakukan secara ekplanatori (Taras et al., 2013 ; Rasool et al., 2018 ; Farmanesh et al., 2020).

Penelitian terdahulu sudah meneliti tentang konsep akulturasi dan pengaruh akulturasi. Tetapi penelitian terdahulu lebih banyak meneliti dalam konteks budaya sosial sedangkan dalam konteks budaya kerja di dalam perusahaan masih terbatas. Sehingga penelitian ini tentang akulturasi budaya kerja karyawan ekspatriat dan lokal dalam perspektif manajemen keberagaman dilakukan.

PT Nusa Halmahera Minerals (PT NHM) merupakan tambang emas terbesar di Maluku Utara, bahkan salah satu terbesar di Indonesia yang terletak di Halmahera Utara yang memiliki karyawan dari berbagai macam latar belakang budaya baik dari Halmahera

Jurnal IImu Sosial dan Humaniora | 546 
Oktadwilaras Anugerah Putri Papuling, Agus Sugiarto | Membangun Manajemen Keberagaman Melalui Akulturasi Budaya Kerja Karyawan Ekspatriat Dan Karyawan Lokal

Utara sampai karyawan ekspatriat dari sejumlah Negara.

Suatu organisasi atau

perusahaan tentunya memiliki pekerja dari berbagai latar belakang dengan globalisasi yang semakin nampak, orang akan bekerja dimana saja. Kendala atau masalah yang sering dihadapi adalah penyesuaian budaya antar karyawan, terjadinya kesalahan pahaman akibat perbedaan sikap dan harapan antara karyawan lokal dan karyawan ekspatriat. Selain permasalahan tersebut, terjadi pula fenomena adaptasi antar budaya sehingga menghasilkan budaya kerja yang mendukung kinerja perusahaan. Berdasarkan fenomena tersebut maka menjadi menarik untuk dilakukan pengkajian tentang akulturasi budaya kerja karyawan ekspatriat dan karyawan lokal PT NHM.

Penelitian ini bertujuan untuk menganalisis bentuk akulturasi budaya kerja di PT NHM, proses akulturasi budaya kerja karyawan ekspatriat dan budaya kerja karyawan lokal, dampak dari akulturasi budaya kerja karyawan ekspatriat dan budaya kerja karyawan lokal dan menganalisis hambatan dan tantangan dalam proses akulturasi budaya kerja karyawan ekspatriat dan budaya kerja karyawan lokal di PT NHM.

Penelitian ini diharapkan menghasilkan temuan yang dapat digunakan sebagai referensi dalam upaya membantu pimpinan perusahaan dalam menciptakan komunikasi yang baik, mengelola keberagaman dan proses penyesuaian budaya kerja. Serta dapat menjadi upaya pengembangan ilmu pengetahuan dalam bidang ilmu sumber daya manusia khususnya terhadap manajemen keberagaman melalui akulturasi budaya kerja ekspatriat dan budaya kerja lokal.

\section{METODE}

Penelitian ini menggunakan jenis penelitian eksploratif dengan pendekatan kualitatif. Penelitian dilaksanakan di PT Nusa Halmahera Minerals Kabupaten Halmahera Utara, Provinsi Maluku Utara. Pengumpulan data yang dilakukan terbatas, karena kondisi pandemi Covid-19 sehingga peneliti dialihkan melakukan wawancara langsung di kantor cabang PT NHM, namun karena di kantor cabang hanya ada karyawan lokal maka peneliti berinisiatif menyiapkan kuesioner secara online. Wawancara berdasarkan kuesioner dilakukan karena kondisi Covid-19 yang membuat tempat penelitian ketat terhadap protokol kesehatan dan orang luar dilarang untuk masuk ke perusahaan induk, terlebih khusus untuk mewawancarai para ekspatriat, peneliti melakukannya secara online dengan menggunakan kuesioner. Hal ini dikarenakan ekspatriat sangat sibuk dan tidak dapat berbahasa Indonesia.

Data diperoleh melalui wawancara secara tatap muka terhadap 3 informan dan tebar kuesioner secara online (Google form) terhadap 2 informan. Sumber data dari lima informan menjadi pokok data penelitian diantaranya karyawan lokal dan ekspatriat Afrika, lima informan tersebut adalah karyawan aktif dan 
Oktadwilaras Anugerah Putri Papuling, Agus Sugiarto | Membangun Manajemen Keberagaman Melalui Akulturasi Budaya Kerja Karyawan Ekspatriat Dan Karyawan Lokal

terikat pada lingkungan yang menjadi sasaran penelitian sehingga informasi yang diperoleh benar-benar valid. Keabsahan data dilakukan dengan triangulasi data, dengan melakukan perbandingan hasil wawancara dengan pendapat pakar atau literatur dan datadata sekunder yang ada (Piperopoulos, 2010). Selanjutnya hasil analisis data akan digunakan untuk mengidentifikasi konteks, menentukan proses, dan mengevaluasi integrasi teoritis (Corbin \& Strauss, 2008).

\section{HASIL DAN PEMBAHASAN}

PT Newcrest dan PT Antam menciptakan suatu usaha bersama di tahun 1994 dalammelakukan eksplorasi pencarian emas di pulau Halmahera. Usaha bersama tersebut secara resmi menemukan emas yang mempunyai nilai ekonomi di Gosowong. Pada 1997, PT Newcrest dan PT Antam membentuk PT Nusa Halmahera Minerals (PT NHM) dan Kontrak Karya antara Pemerintah Indonesia dan PT NHM ditandatangani pada tanggal 28 April 1997, disusul kemudian dengan rampungnya studi keteknikan, studi kelayakan dan studi dampak lingkungan. Bijih emas dituangkan pertama kali di Gosowong pada Juli 1999. PT NHM menerapkan visi PT Newcrest menjadi suatu tambang pilihan bagi seluruh pemangku kepentingan termasuk karyawan dan kontraktor, masyarakat dimana perusahaan beroperasi serta para pemegang saham. Tanggung jawab sosial, keselamatan dan keberlangsungan adalah dasar panduan utama bagi visi PT NHM.
Perusahaan mencapai visi dengan hidup dan bekerja berdasar pada nilainilai kejujuran dan integritas, performa kerja yang tinggi, bekerjasama, menghargai inovasi dan pemecahan masalah serta peduli terhadap orang lain.

Pada Februari 2020 PT Indotan membeli saham mayoritas (75\%) di PT NHM dari perusahaan Australia, PT Newcrest Mining Ltd. Sementara PT Aneka Tambang (Antam) tetap memegang $25 \%$ saham lainnya. PT $\mathrm{NHM}$ merupakan perusahaan patungan antara PT Indotan Halmahera Bangkit (Indotan) 75\% dan PT Aneka Tambang Tbk (Antam) 25\% saham dan mengoperasikan Tambang Emas Gosowong yang terletak di Pulau Halmahera di bagian Timur Indonesia. PT NHM mengelola tambang emas gosowong yang berlokasi di Kabupaten Halmahera Utara, Provinsi Maluku Utara di bawah kepemimpinan Robert Nitiyudo Wachjo yang merupakan pemilik sekaligus Presiden Direktur PT NHM.

Karyawan yang bekerja di PT $\mathrm{NHM}$, terdiri dari masyarakat asal Provinsi Maluku Utara, termasuk asal Kabupaten Halmahera Utara, karyawan nasional dari berbagai Provinsi di Indonesia dan sebagiannya adalah ekspatriat dari sejumlah negara. Jumlah karyawan lokal asal Provinsi Maluku Utara sebanyak 515 orang, karyawan dari berbagai Provinsi sebanyak 393 orang dan ekspatriat sebanyak 26 orang. Saat pemindahan kepemilikan dari PT Newcrest kepada PT Indotan, presiden direktur menciptakan terobosan-terobosan dan 
Oktadwilaras Anugerah Putri Papuling, Agus Sugiarto | Membangun Manajemen Keberagaman Melalui Akulturasi Budaya Kerja Karyawan Ekspatriat Dan Karyawan Lokal

menciptakan harapan bertambahnya umur tambang untuk beberapa tahun lebih lama dari yang diperkirakan sebelumnya bahwa umur tambang hanya bertahan sekitar dua tahun.

\section{Karakteristik Informan}

Kelima karyawan PT NHM yang dijadikan informan ditentukan oleh manajemen PT NHM dipilih berdasarkan kesediaan mereka dalam mengisi kuesioner dan wawancara secara langsung. Kelima informan tersebut dipilih karena merupakan karyawan aktif, yang memiliki jabatan, dan sudah lama bekerja di PT NHM, sehingga banyak informasi dan pengalaman kerja yang didapat.

Tabel 1.Profil Karyawan PT NHM

\begin{tabular}{|c|c|c|c|c|}
\hline Nama & Jabatan & $\begin{array}{l}\text { Jenis } \\
\text { Kelamin }\end{array}$ & Asal & $\begin{array}{l}\text { Lama } \\
\text { Kerja } \\
\text { (Tahun) }\end{array}$ \\
\hline RM & $\begin{array}{l}\text { Super- } \\
\text { intendent } \\
\text { CSR }\end{array}$ & Laki-laki & $\begin{array}{l}\text { Malifut, } \\
\text { Halmahera } \\
\text { Utara }\end{array}$ & 14 \\
\hline SA & $\begin{array}{l}\text { Supervisor } \\
\text { Ekonomi } \\
\text { CSR }\end{array}$ & Laki-laki & Ternate & 2 \\
\hline AT & $\begin{array}{l}\text { HR } \\
\text { Training } \\
\text { Officer }\end{array}$ & Laki-laki & $\begin{array}{l}\text { Galela, } \\
\text { Halmahera } \\
\text { Utara }\end{array}$ & 7 \\
\hline $\mathrm{JE}$ & $\begin{array}{l}\text { Electrical } \\
\text { Specialist }\end{array}$ & Laki-laki & Afrika & 14 \\
\hline SP & $\begin{array}{l}\text { Koordinator } \\
\text { Lapangan } \\
\text { CSR }\end{array}$ & Laki-laki & $\begin{array}{l}\text { Kao Barat, } \\
\text { Halmahera } \\
\text { Utara }\end{array}$ & 6 \\
\hline
\end{tabular}

Kelima karyawan tersebut salah satunya merupakan karyawan ekspatriat yang berasal dari Afrika, dari beberapa karyawan ekspatriat yang bekerja di perusahaan tersebut yang merespon serta bersedia memberikan informasi adalah salah satu karyawan ekspatriat asal Afrika, dan keempat lainnya merupakan karyawan lokal yang berasal dari pulau Halmahera.

\section{Budaya Kerja PT NHM}

Budaya kerja yang diciptakan di PT NHM adalah budaya yang humanis, komunikatif, transparan dan terukur sosial kemanusiaanya. Secara internal karyawan PT NHM merasakan perubahan positif yang luarbiasa mengesankan, mulai dari bonus yang tinggi saat produksi perusahaan yang melebihi target yang telah direncanakan, direkrutnya para kontraktor menjadi karyawan permanen PT NHM, semakin banyak karyawan asal desa lingkar tambang yang masuk bekerja di PT NHM, serta kualitas hidup di kawasan tambang gosowong. Kebijakan internal perusahaan PT NHM Gosowong ada gebrakan supporting yang luar biasa kepada karyawan dalam bentuk pemberian bonus produksi dengan jumlah puluhan milyar yang dibagi sesuai kesepakatan bersama, hal itu belum pernah dilakukan oleh Newcrest sebelumnya, serta pemberian kepercayaan kepada karyawan lokal untuk menduduki jabatan strategi seperti Manager HRD dan SP/CSR dan ada juga sejumlah kebijakan lain yang menguntungkan karyawan.

PT NHM sangat berfokus pada keselamatan, kesehatan dan kesejahteraan semua karyawan termasuk masyarakat sekitar lokasi perusahaan beroperasi (masyarakat lingkar tambang). Sistem pengelolaan keselamatan dan kesehatan di antaranya semua aspek dalam operasi tambang dan mendukung fungsi-fungsi, 
Oktadwilaras Anugerah Putri Papuling, Agus Sugiarto | Membangun Manajemen Keberagaman Melalui Akulturasi Budaya Kerja Karyawan Ekspatriat Dan Karyawan Lokal

serta berlaku bagi semua karyawan dan kontraktor.

Saat ini PT NHM berinvestasi secara luas pada inisiatif masyarakat yang memberikan manfaat dengan hadirnya kegiatan pertambangan, membantu pemenuhan kebutuhan masyarakat dan memperkuat pembangunan sosial ekonomi di daerah. PT NHM menempatkan sumber daya manusia sebagai asset paling berharga perusahaan, para karyawan dan kontraktor sangat beragam dalam berbagai hal dan perpaduan gender, budaya serta latar belakang membentuk kekuatan utama atas keberhasilan perusahaan. Sumber daya manusia merupakan bagian penting dalam memastikan keberlanjutan dan pertumbuhan operasi tambang di Gosowong.

\section{Karakter dan Budaya Kerja Karyawan Ekspatriat}

Salah satu Karyawan Ekspatriat yang bekerja di PT NHM dan bersedia memberikan informasi adalah orang Afrika, memiliki karakter yang penuh semangat dan energi, suka bekerja, disiplin, berkomitmen, menyukai tantangan, mampu menyesuaikan diri, berani untuk menentukan nasib sendiri tanpa adanya rasa takut, dan realistis. Budaya kerja karyawan Ekspatriat Afrika dikenal lebih mengutamakan kualitas pekerjaan, dan merupakan tipe orang yang individual karena bagi karyawan Ekspatriat Afrika pekerjaan menjadi prioritas utama. Ekspatriat Afrika juga memiliki etos kerja yang baik, dapat dilihat dari budaya disiplin yang diterapkan dalam diri, kemudian memiliki motivasi yang baik dan merupakan individu yang tetap berpegang teguh terhadap komitmen.

\section{Karakter dan Budaya Kerja Karyawan Lokal}

Karyawan lokal yang bekerja di PT NHM sangat beragam sebagian berasal dari pulau Halma-hera dan diluar pulau Halmahera. Namun hampir sebagian besar karyawan lokal berasal dari pulau Halmahera. Orang Halmahera memiliki karakter pemberani, pekerja keras, memiliki sifat terbuka, gotong-royong, mandiri, mudah untuk bersosialisasi dan beradaptasi, menghargai adat dan kebudayaan, dan berwatak keras kepala. Budaya kerja orang Halmahera memiliki etos kerja yang baik, dan pekerja keras. Dalam bekerja, orang Halmahera merupakan tipe individu yang senang untuk bekerja sama, serta dapat menciptakan relasi yang baik dengan rekan kerja lainnya, dan tidak membeda-bedakan (suku, agama, budaya).

\section{Bentuk Akulturasi budaya kerja}

Diantara kelima responden salah satunya merupakan Ekspatriat. Kelima responden tersebut adalah $R M$, $S A, A T$, JE, dan SP. Profil responden pertama ialah $R M$ karyawan yang berasal dari Malifut, Halmahera Utara dan sudah bekerja di PT NHM selama empatbelas tahun. Dalam satu tahun terakhir $(R M)$ diangkat menjadi pimpinan di departement CSR. RM mengaku sebagai seorang pemimpin di dalam department ia tetap menerima budaya yang diterapkan di dalam 
Oktadwilaras Anugerah Putri Papuling, Agus Sugiarto | Membangun Manajemen Keberagaman Melalui Akulturasi Budaya Kerja Karyawan Ekspatriat Dan Karyawan Lokal

perusahaan. Perusahaan menerapkan budaya kerja yang sangat baik dengan berdasar pada panduan kerja yang diterapkan dan ditanamkan, menyangkut keselamatan (safety), struktur kerja dan kesejahteraan karyawan dalam bekerja. RM harus menjadi contoh yang baik untuk karyawan lainnya dan sebagai pemimpin RM harus mampu menciptakan relasi dan komunikasi yang baik dengan karyawannya. Sejauh ini perusahaan masih tetap menerapkan budaya yang ada sebelumnya, karena budaya yang sudah ada sebelumnya dirasa cukup bahkan sangat baik sehingga tidak perlu adanya penggantian budaya baru.

Sementara responden yang kedua ialah $S A$ karyawan yang berasal dari Ternate, dan sudah bekerja di PT NHM selama satu tahun sebelas bulan. SA merupakan karyawan yang bekerja sebagai Supervisor Ekonomi di department CSR PT NHM. SA mengaku bahwa budaya kerja yang diterapkan di dalam perusahaan ialah budaya kedisiplinan, budaya keselamatan dalam bekerja, serta prosedur kerja yang jelas arahnya. Namun ada sedikit perubahan manajemen dikarenakan terjadinya perubahan kepemilikkan saham dari sebelumnya yaitu dari Newcrest ke Indotan. Respon SA terhadap budaya yang diterapkan di dalam perusahaan sangat baik dan sangat respect dengan model manajemen yang ada di perusahaan. Begitu juga dengan aturan-aturan yang diberikan sangat tegas, manakala melanggar akan diberikan sanksi, administratif, bahkan sampai yang terburuk adalah pemecatan.

Responden yang ketiga ialah AT karyawan yang berasal dari Galela, Halmahera utara dan sudah bekerja di PT NHM selama tujuh tahun di posisi HR Trainning Officer. AT mengaku bahwa budaya yang diterapkan dalam perusahaan adalah Rooster empat:dua artinya empat minggu kerja dan dua minggu cuti. Respon AT terhadap budaya kerja yang diterapkan diperusahaan adalah baik, AT mengaku bahwa di perusahaan adanya perubahan budaya kerja, misalnya dalam PKB (Panduan kerja bersama) setiap periode selalu diganti dan isinya kadang ada yang direvisi ataupun dihilangkan. Jawaban yang diberikkan sangat singkat, terlihat bahwa AT adalah orang yang to the point, disiplin dan cenderung sangat sibuk.

Selanjutnya responden keempat ialah JE merupakan karyawan yang berasal dari Negara Afrika, bekerja di PT NHM selama empatbelas tahun dan di posisi Electrical Spesialist. JE merupakan salah satu karyawan Ekspatriat yang sampai saat ini masih tetap bertahan bekerja di perusahaan NHM. Pandangan JE terhadap budaya kerja yang diterapkan perusahaan, hal ini tampak dari hasil wawancara di bawah ini.

"Lots of rules and regulations differ from company to company. But any rule that is set by company must be respected."

Berdasarkan kutipan di atas
dapat dipahami bahwa apapun
aturan/budaya yang diterapkan di


dalam perusahaan harus dihormati. JE mengaku bahwa dia dapat menerima dan beradaptasi dengan budaya yang diterapkan di dalam perusahaan karena untuk kebaikan dirinya sendiri. JE mengatakan bahwa dari waktu ke waktu pastinya berubah begitu juga dengan budaya yang diterapkan di dalam perusahaan pastinya berubah, karena selalu ada ruang untuk perbaikan/pembaharuan. Jawaban yang diberikan JE melalui kuesioner online sangat singkat dan tidak banyak. Terlihat JE adalah orang yang sangat sibuk dan lebih memprioritaskan pekerjaan.

Responden yang kelima ialah $(S P)$ karyawan yang berasal dari Kao barat, Halmahera utara, bekerja di PT NHM selama enam tahun sebagai Koordinator lapangan CSR. SP mengaku bahwa budaya kerja yang diterapkan di dalam perusahaan mengikuti prosedur yang diterapkan yaitu PKB (Panduan kerja bersama) dan struktur kerja. SP mengatakan bahwa adapun program rutin yang dilakukan perusahaan untuk masyarakat lingkar tambang diantaranya program kesehatan, pemberdayaan dan pendidikan. SP dapat menerima budaya yang diterapkan di dalam perusahaan, hal tersbut tampak dari dari hasil wawancara di bawah ini.

"Untuk saat ini saya dapat menerima, karena beda jamannya dengan masa kepemilikkan Newcrest. Sehingga budaya kerja yang diterapkan saat ini sudah sangat baik."
Dari kutipan di atas dapat dipahami bahwa SP dapat menerima budaya yang diterapkan di dalam perusahaan karena sebagai seorang karyawan yang bekerja di posisi Koordinator lapangan sudah sangat nyaman dengan gaya manajemen yang ada saat ini. SP mengaku bahwa budaya kerja yang ada di perusahaan terjadi penggantian aturan, hal tersebut tampak pada hasil wawancara di bawah ini.

"Budaya kerja berubah terlebih khusus di bagian CSR, karena tidak lagi berkantor di dalam site, melihat kondisi dan situasi covid-sembilanbelas yang ada saat ini sehingga kami harus mengikuti protokol yang diterapkan perusahaan."

Berdasarkan kutipan di atas dapat dipahami bahwa ada sedikit perubahan peraturan yang mana awalnya department CSR berkantor di dalam site (perusahaan induk) karena adanya covid-sembilanbelas sehingga sangat ketat terhadap protokol yang ada dan mengakibatkan departement tersebut harus dialihkan berkantor di luar site. Namun SP tidak keberatan terhadap aturan yang diterapkan saat ini. SP tetap menjalankan tanggungjawabnya dengan baik dan tetap menjalin relasi yang baik dengan pimpinan, karyawan, dan masyarakat lingkar tambang. Uraian hasil wawancara, dapat disimpulkan tentang bentuk akulturasi dalam beberapa budaya kerja seperti terlihat pada Tabel 2. 
Oktadwilaras Anugerah Putri Papuling, Agus Sugiarto | Membangun Manajemen Keberagaman Melalui Akulturasi Budaya Kerja Karyawan Ekspatriat Dan Karyawan Lokal

Tabel 2. Temuan Analisa Bentuk Akulturasi

\begin{tabular}{lll}
\hline $\begin{array}{l}\text { Budaya kerja } \\
\text { Lokal }\end{array}$ & $\begin{array}{l}\text { Budaya kerja } \\
\text { Ekspatriat }\end{array}$ & $\begin{array}{l}\text { Budaya } \\
\text { Perusahaan }\end{array}$ \\
\hline $\begin{array}{l}\text { Terbuka } \\
\text { Dapat } \\
\text { menciptakan } \\
\text { relasi yang } \\
\text { baik }\end{array}$ & $\begin{array}{l}\text { Menghormati } \\
\text { dan menerima } \\
\text { aturan yang } \\
\text { ada }\end{array}$ & $\begin{array}{l}\text { Keselamatan } \\
\text { dalam bekerja }\end{array}$ \\
$\begin{array}{l}\text { Senang } \\
\text { bekerja } \\
\text { secara tim }\end{array}$ & $\begin{array}{l}\text { Bertanggung- } \\
\text { jawab }\end{array}$ & Komunikatif \\
Pekerja keras & $\begin{array}{l}\text { Penuh } \\
\text { semangat }\end{array}$ & $\begin{array}{l}\text { Struktur kerja } \\
\text { terarah }\end{array}$ \\
& $\begin{array}{l}\text { Menghargai } \\
\text { waktu }\end{array}$ & \\
\hline
\end{tabular}

Seperti yang dijelaskan di atas, ada sedikit perubahan manajemen/peraturan perusahaan dikarenakan terjadinya perubahan kepemilikkan saham sebelumnya yaitu dari Newcrest ke Indotan, menghadapi hal seperti itu $R M, S A, A T, J E$, dan $S P$ mengaku bahwa mereka dapat menerima budaya yang diterapkan di dalam perusahaan saat ini.

\begin{tabular}{lcr}
\multicolumn{1}{c}{ Di zaman yang } & semakin \\
berkembang & ini sudah & banyak \\
terjadinya & perpaduan & yang \\
menimbulkan & perubahan & suatu
\end{tabular}
kebudayaan meskipun terdapat jenis kebudayaan asing yang masuk dan tidak merubah kebudayaan yang telah ada. Menurut Barry (dalam Somovar et al., 2010) Akulturasi sebagai proses dari perubahan budaya dan psikologis yang terjadi sebagai akibat dari hubungan antara dua atau lebih kelompok budaya dan anggotanya. Hasil penelitian menunjukkan bahwa pada PT NHM adanya perpaduan yang menimbulkan perubahan yaitu budaya perusahaan yang menjadi penengah antara budaya lokal dan budaya ekspatriat. Terdapat dua bentuk akulturasi, yaitu terjadi penggantian dan penambahan budaya, yang mana dalam hal ini unsur budaya lama perusahaan digantikan dengan budaya yang baru yang lebih praktis dan efisien sehingga dapat mengkombinasikan antara dua atau lebih unsur budaya sehingga memberikan nilai tambah pada unsur tersebut.

\section{Proses Akulturasi Budaya Kerja}

Manusia tidak bisa menghindari dirinya dari kehidupan sosialnya. Kehidupan sosial tersebut ditunjang oleh komunikasi sehingga komunikasi merupakan hal yang sangat penting (Mulyanan \& Rakhmat, 2009). Komunikasi antarbudaya dipengaruhi oleh berbagai faktor yaitu faktor budaya, sosiobudaya, psikobudaya dan lingkungan. Faktor-faktor ini memerlukan proses adaptasi dan penyesuaian diri atau biasa disebut sebagai akulturasi yang dijadikan sebagai bahasa rujukan kepada penyesuaian individu terhadap suatu budaya baru. Proses Akulturasi akan terus berlangsung selama imigran mengadakan kontak langsung (Kim dalam Mulyanan \& Rakhmat, 2009). Kebanyakan individu yang baru menyesuaikan diri mengalami kesulitan yang signifikan ketika beradaptasi dengan budaya orang lain, seperti yang dinyatakan oleh (Westood, 1999), "Pendatang baru mungkin tidak siap untuk belajar dan mempraktikan perilaku sosial yang pantas dalam

Jurnal IImu Sosial dan Humaniora | 553 
Oktadwilaras Anugerah Putri Papuling, Agus Sugiarto | Membangun Manajemen Keberagaman Melalui Akulturasi Budaya Kerja Karyawan Ekspatriat Dan Karyawan Lokal

budaya baru selama masa-masa awal. Bukan tidak biasa jika pendatang baru diliputi oleh tuntutan dan tantangan dalam tempat yang baru.

Taras et al. (2013) menjelaskan bahwa pendidikan yang diterima di negara tuan rumah ternyata mempercepat akulturasi. Namun, efek dari keduanya tidak serta merta berbanding terbalik. Pengaruh pendidikan di negara tuan rumah lebih kuat dan merupakan prediktor yang sangat baik untuk tingkat akulturasi, sedangkan pengaruh pendidikan negara asal terbatas sehingga lebih banyak pendidikan sebelum imigrasi tidak selalu berarti kurang akulturasi.

RM mengaku bahwa membutuhkan proses selama beberapa bulan untuk dapat beradaptasi dengan budaya kerja yang diterapkan perusahaan. Kondisi-kondisi tertentu yang mengharuskan untuk dapat beradaptasi, sehingga mendorong diri sendiri untuk bisa menyesuaikan dengan kondisi yang ada di dalam perusahaan. Sebagai seorang pemimpin harus punya komunikasi yang baik dengan karyawan. RM merupakan seorang pimpinan yang bijaksana, adil dalam bersikap dan berhati-hati dalam membuat keputusan, menghargai perasaan orang lain, serta bijaksana dalam melihat kondisi yang ada. RM mengaku bahwa ia dapat menerima perbedaan budaya dari rekan kerjanya, hal tersebut tampak dari hasil wawancara di bawah ini.

"Dari sisi pekerjaan kita adalah satu, jadi tidak ada yang dibeda-bedakan. Ibarat sebuah perahu, kita berlayar dan mempunyai tujuan yang sama. Karena kita satu tim, kita tetap fokus untuk menuju satu tujuan dan punya komitmen dalam bekerja."

Adapun proses yang dirasakan oleh SA, ia mengatakan bahwa membutuhkan waktu sekitar satu sampai dua bulan untuk beradaptasi dengan budaya kerja yang ada di perusahaan dan sampai saat ini masih berproses untuk penyesuaian dengan manajemen yang baru. Usaha yang dilakukan SA dalam beradaptasi ialah tetap berproses dan belajar untuk menyesuaikan diri dengan budaya yang ada. SA merupakan karyawan yang cepat untuk beradaptasi dengan lingkungan tempat ia bekerja didukung oleh motivasi dan tekad yang kuat dari dirinya sendiri. Walaupun pada awalnya sedikit terasa canggung, tetapi tidak mematahkan semangatnya untuk dapat membangun/menciptakan komunikasi yang baik di dalam department tempat SA bekerja.

AT mengaku bahwa tidak butuh waktu lama, biasanya satu minggu untuk beradaptasi dengan budaya kerja yang diterapkan di perusahaan, usaha untuk beradaptasi yang dilakukan AT adalah membaca aturan tersebut dan jika tidak paham maka dia harus bertanya. AT mengaku bahwa cara dia berkomunikasi dengan karyawan lainnya dengan memperhatikan dasarnya yaitu saling menghargai. AT juga dapat menerima perbedaan budaya dari rekan kerjanya, hal tersebut tampak dari hasil wawancara.

"Karena masing-masing daerah ada budaya dan jika itu baik atau tidak bertentangan dengan kepercayaan, bisa diterima bahkan bisa diikuti juga."

Jurnal IImu Sosial dan Humaniora | 554 
Oktadwilaras Anugerah Putri Papuling, Agus Sugiarto | Membangun Manajemen Keberagaman Melalui Akulturasi Budaya Kerja Karyawan Ekspatriat Dan Karyawan Lokal

Selanjutnya JE mengaku bahwa waktu yang diperlukan untuk dapat beradaptasi adalah segera saat mulai bekerja di perusahaan, JE memberikan komitmen penuh untuk setiap aturan/budaya dan regulasi perusahaan tempat ia bekerja. Karena JE merupakan ekspatriat maka caranya berkomunikasi dengan karyawan lainnya melalui email, rapat dan juga telepon. Namun JE dapat menerima perbedaan budaya dengan rekan kerjanya karena menurut JE siapapun bisa beradaptasi dan mengerti.

SP mengaku bahwa setelah masa uji coba dalam perusahaan tiga bulan, SP sudah bisa menyesuaikan, apalagi di posisinya kerja, ia mengaku sudah banyak cara kerja yang dipahami. SP juga dapat menerima perbedaan budaya dari rekan kerja. Uraian hasil wawancara, dapat disimpulkan tentang berbagai proses dalam beberapa tahapan proses akulturasi seperti terlihat pada Gambar 1.

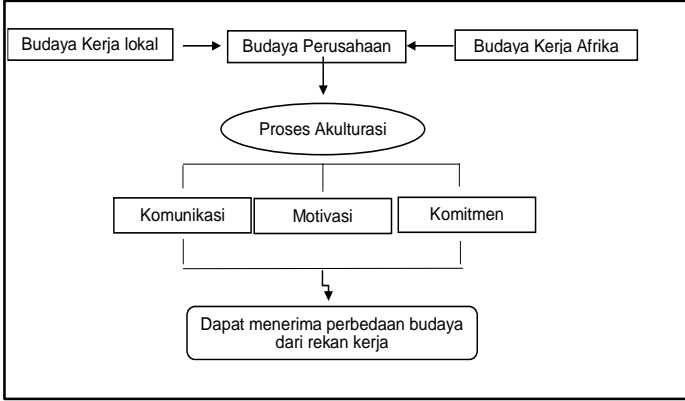

Gambar 1. Analisa Proses Akulturasi

Hasil penelitian sebelumnya dari Fitriana et al., (2018) menunjukkan bahwa terdapat pengaruh signifikan antara Akulturasi dalam proses interaksi antarbudaya terhadap kesadaran budaya berbahasa di kalangan mahasiswa Sulawesi Selatan di Kota Bandung. Namun, komunikasi personal dan komunikasi sosial memiliki pengaruh yang sifatnya signifikan terhadap kesadaran budaya berbahasa.

Hasil penelitian menunjukkan bahwa, proses terjadinya akulturasi dapat dilihat dari bertemunya dua kebudayaan yang ada di dalam perusahaan yaitu Indonesia dan Afrika. Meskipun kedua budaya ini memiliki perbedaan latar belakang dan kebudayaan, namun masing-masing dapat menerima nilai-nilai bawaannya. PT NHM menerapkan budaya yang harus diterima dan diterapkan bersama oleh setiap karyawan yang bekerja di perusahaan tersebut. Budaya yang ada di dalam perusahaan merupakan penengah yang dapat menyatukan perbedaan budaya antara karyawan Indonesia (lokal) dengan karyawan Afrika (ekspatriat) tanpa menghilangkan identitas kebudayaan dari masingmasing.

\section{Dampak Akulturasi Budaya Kerja}

RM mengaku bahwa dampak positif yang diciptakan perusahaan sangat luar biasa, karena perusahaan selalu mengutamakan safety terhadap semua karyawannya sehingga keselamatan setiap karyawan terjamin. Namun untuk dampak negatifnya saat ini tidak ada, karena perusahaan selalu cepat dalam menyikapi setiap masalah yang ada. RM mengaku bahwa budaya kerja yang sudah diterapkan perusahaan harus tetap dipertahankan. 
Oktadwilaras Anugerah Putri Papuling, Agus Sugiarto | Membangun Manajemen Keberagaman Melalui Akulturasi Budaya Kerja Karyawan Ekspatriat Dan Karyawan Lokal

Kondisi lingkungan juga berpengaruh, karena menurutnya dimana kita di tempatkan kita harus dapat melihat dan mempelajari kondisi lingkungan sehingga dapat membangun komunikasi yang baik.

Adapun dampak positif yang dirasakan oleh SA ialah membangun karakter secara pribadi dan tentunya membangun karakter yang baik di dalam department. Merubah cara berpikir jadi lebih baik, lebih global, lebih luas tidak hanya satu suku/budaya. Namun SA tidak merasakan dampak negatif dari akulturasi budaya kerja, karena menurut SA budaya yang ada bagus untuk kebaikkan secara pribadi maupun perusahaan sehingga tidak ada aturan yang merugikan. Meskipun budaya kerja yang ada sudah bagus tetapi dunia semakin hari semakin berkembang, baik teknologi maupun informasi sehingga tetap harus mengikuti perkembangan jaman tersebut. Menurut SA kondisi lingkungan juga berpengaruh terhadap komunikasi.

Selanjutnya AT mengaku bahwa dampak positif yang dirasakan dampaknya besar dan tidak ada dampak negatifnya. Menurut AT budaya kerja yang diciptakan di dalam perusahaan dapat dipertahankan ataupun diperbaharui tetapi tergantung dengan situasinya. AT mengaku bahwa jika kondisi lingkungan baik maka mudah berkomunikasi dengan orang lain, sebaliknya jika situasinya tidak memungkinkan kadang perlu usaha keras untuk menciptakan komunikasi yang baik.
Dampak yang dirasakan oleh JE adalah banyak dampak positif yang diraih dan dia mencoba untuk membuatnya sukses dan berusaha untuk tetap seperti itu. JE mengaku bahwa apapun dampak negatifnya ia akan kembali mencoba untuk membuatnya lebih baik. JE juga mengaku bahwa budaya kerja yang diciptakan di perusahaan tetap harus di pertahankan karena jika banyak perubahan bisa membingungkan. JE mengaku bahwa kondisi lingkungan tidak mempengaruhinya dalam berkomunikasi, karena menurut JE dia akan memastikan, menerjemahkan dan memahami nya sehingga tidak dapat mempengaruhinya.

Beda halnya dengan SP, SP mengaku bahwa dampak positif dari budaya yang diciptakan di dalam perusahaan membuatnya dapat mengetahui bagaimana cara berkomunikasi dan bersosialisasi dengan setiap orang. Tetapi SP juga merasakan beberapa dampak negatif, namun dampak tersebut lebih mengarah terhadap keadaan alam tempat ia bekerja. SP mengaku bahwa budaya kerja yang diciptakan tidak perlu diubah karena menurut SP budaya yang diciptakan dan diterapkan masih baik adanya, ia juga mengatakan bahwa kondisi lingkungan sangat berpengaruh terhadap komunikasi, khususnya komunikasi secara online sangat terhambat dikarenakan keterbatasan jaringan di tempat kerja. Hasil wawancara, dapat disimpulkan tentang berbagai dampak dalam beberapa bentuk akulturasi seperti terlihat pada Tabel 3.

Jurnal IImu Sosial dan Humaniora | 556 
Oktadwilaras Anugerah Putri Papuling, Agus Sugiarto | Membangun Manajemen Keberagaman Melalui Akulturasi Budaya Kerja Karyawan Ekspatriat Dan Karyawan Lokal

Tabel 3. Analisa Dampak Akulturasi

\begin{tabular}{ll} 
Bentuk Akulturasi & Dampak Akulturasi \\
\hline Addition & $\begin{array}{l}\text { Membangun karakter } \\
\text { yang baik } \\
\text { Perubahan proses } \\
\text { budaya lama yang } \\
\text { masih berfungsi } \\
\text { ditambah dengan } \\
\text { unsur budaya yang } \\
\text { baru sehingga akan baik } \\
\text { memberikan nilai } \\
\text { lebih pada } \\
\text { kebudayaan } \\
\text { tersebut } \\
\\
\\
\\
\\
\begin{array}{l}\text { Berpikir lebih Global } \\
\text { Dapat membangun dan } \\
\text { menjalin komunikasi }\end{array} \\
\\
\text { yang baik } \\
\text { Bersosialisasi dengan } \\
\text { banyak orang }\end{array}$ \\
\hline
\end{tabular}

Menurut Saebani
akulturasi dapat berdampak pada
perubahan sikap dan perilaku
masyarakat, diantaranya; terjadinya
perubahan cara pandang individu
tentang kehidupan masyarakat, terjadi
perubahan dalam hubungan sosial di
masyarakat, wawasan dan
pengetahuan masyarakat semakin terbuka luas, dan terjadi perubahan mentalitas, rasa malu serta keahlian masyarakat. Hasil penelitian menunjukkan banyak dampak positif yang diraih oleh setiap karyawan PT NHM, diantaranya terjadi perubahan cara pandang individu mengenai perbedaan budaya, mengubah cara berpikir menjadi lebih baik, lebih luas/global, dan dengan adanya perbedaan budaya tersebut setiap individu dapat mengetahui cara berkomunikasi dan cara bersosialisasi yang baik dengan setiap karyawan baik ekspatriat maupun lokal di dalam perusahaan tersebut.

\section{Hambatan dan Tantangan Akulturasi Budaya Kerja \\ Selain adanya dampak} akulturasi maka pastinya akan ada juga hambatan dan tantangan dari akulturasi budaya kerja. Tetapi RM mengaku bahwa untuk saat ini tidak ada hambatan dan tantangan yang ia rasakan selama bekerja di perusahaan NHM. Karena RM memiliki motivasi dan berbagi motivasi tersebut dengan rekan kerjanya terkait menghadapi hambatan dan tantangan.

Sama halnya dengan RM, SA mengatakan bahwa:

"Tidak ada masalah, terutama dalam hal komunikasi. Karena kita di sini walaupun berbeda suku dan daerah terutama lokal, kita tetap menggunakan bahasa Indonesia yang baik sehingga mudah untuk dimengerti dan dipahami. Untuk ekspatriat sendiripun kita harus menyesuaikan dengan bahasa mereka, walaupun terbatabata tetapi kita tetap membangun komunikasi yang baik."

Berdasarkan kutipan di atas dapat dipahami bahwa SA merupakan individu yang mudah untuk bersosialisasi dan beradaptasi dengan lingkungan tempat ia bekerja. SA merupakan tipe individu yang punya rasa ingin tahu dan mau selalu belajar mencoba hal-hal yang menantang.SA mengaku bahwa ia tetap belajar dan saling mempelajari budaya serta karakter rekan kerjanya. Kaitannya berkomunikasi dengan para ekspatriat menyangkut bahasa, menurutnya harus 
Oktadwilaras Anugerah Putri Papuling, Agus Sugiarto | Membangun Manajemen Keberagaman Melalui Akulturasi Budaya Kerja Karyawan Ekspatriat Dan Karyawan Lokal

belajar melalui google translate, bahkan menggunakan teknologi dan hal-hal lainnya. Belajar untuk menyesuaikan diri dan mengambil hal-hal yang positif yang dapat membangun.

AT mengaku bahwa ia merasakan beberapa hambatan dan tantangan dari proses penyesuaian, dikarenakan informasi yang kurang di sosialisasikan, sehingga menurut AT harus ada sosialisasi. Namun untuk menghadapi hambatan dan tantangan tersebut AT selalu berusaha untuk tetap berpikir positif.

Selanjutnya JE mengaku bahwa apapun hambatan dan tantangan yang dialami ia tetap melakukan perencanaan tetapkan target dan kerja keras untuk mencapai target tersebut. Cara JE dalam mengatasi hambatan dan tantangan ialah mencoba memberikan yang terbaik, serta tetap menghormati budaya yang ada dalam perusahaan dan menerapkannya. JE mengaku bahwa selalu memotivasi dirinya untuk jadi citra positif, pantang menyerah, jalani hidup sepenuhnya serta tambahkan pemikiran positif setiap hari dalam pertemuan dengan rekan kerja di department yang posisinya di bawahnya.

SP mengalami beberapa hambatan dan tantangan yang lebih mengarah ke keadaan tempat dimana ia bekerja, dikarenakan letak dan jarak kantor cabang SP bekerja lumayan jauh dari jalan raya dan perusahaan induk, sehingga mengakibatkan keterbatasan jaringan dan jarak. Meskipun demikian tidak mematahkan semangat dan usaha dari SP untuk tetap membangun komunikasi dengan pimpinan sehingga semua informasi dapat tersampaikan dan masalah yang terjadi dapat diselesaikan bersama. Hasil wawancara, dapat disimpulkan tentang berbagai hambatan dalam beberapa tahapan proses akulturasi seperti terlihat pada Tabel 4.

Tabel 4. Analisa Hambatan dan Tantangan Akulturasi

\begin{tabular}{ll}
\hline Tahapan Akulturasi & $\begin{array}{l}\text { Hambatan/ Tantangan } \\
\text { yang dihadapi }\end{array}$ \\
\hline Proses penyesuaian & $\begin{array}{l}\text { Kurangnya informasi } \\
\text { yang disosialisasikan } \\
\text { sehingga harus ada } \\
\text { sosialisasi }\end{array}$ \\
\hline
\end{tabular}

Hambatan Akulturasi yaitu komunikasi yang merupakan hal terpenting dalam melakukan interaksi antar individu ketika menempati lingkungan baru. Penghambat dalam komunikasi antarbudaya yang menunjukkan sifat antara lain; mengabaikan perbedaan antara kelompok kultural yang berbeda, melanggar adat kebiasaan kultural, dan menilai perbedaan secara negatif dan kejutan budaya (Fajar, 2009 dalam Fathonah, 2017).

Hasil penelitian menunjukkan bahwa, tidak begitu banyak hambatan dan tantangan yang ada di dalam perusahaan terutama dalam hal berkomunikasi, karena setiap karyawan menggunakan bahasa yang mudah dipahami yaitu bahasa Indonesia, untuk berkomunikasi dengan para ekspatriat karyawan lokal berusaha untuk menyesuaikan dengan bahasa mereka meskipun terbata-bata serta dapat menggunakan bahasa isyarat. Namun melihat perkembangan dunia yang semakin hari semakin berkembang dan 
Oktadwilaras Anugerah Putri Papuling, Agus Sugiarto | Membangun Manajemen Keberagaman Melalui Akulturasi Budaya Kerja Karyawan Ekspatriat Dan Karyawan Lokal

canggih, sehingga dapat memudahkan karyawan ekspatriat dan lokal untuk berkomunikasi secara online melalui via email, dan telepon. PT NHM memiliki karyawan yang ditugaskan untuk menjadi penerjemah sehingga tidak menjadi hambatan dalam berkomunikasi antara karyawan lokal dan ekspatriat.

\section{SIMPULAN DAN SARAN}

\begin{tabular}{lrr}
\multicolumn{2}{c}{ Pengelolaan } & manajemen \\
keberagaman & melalui & akulturasi \\
berdampak & terhadap & kinerja \\
perusahaan, & dengan & adanya
\end{tabular}
perbedaan budaya pada akhirnya mempengaruhi perilaku setiap individu, salah satu contohnya karyawan lokal perusahaan dapat mempelajari budaya disiplin dalam bekerja yang diterapkan oleh karyawan ekspatriat Afrika di PT NHM. Perusahaan juga memiliki budaya tersendiri yang diterapkan sebagai penengah antara budaya lokal dan ekspatriat, sehingga dari perpaduan yang menimbulkan perubahan terdapat dua bentuk akulturasi yaitu penggantian dan penambahan budaya, dalam hal ini unsur budaya lama perusahaan diganti dengan budaya baru yang lebih praktis dan efisien, sehingga dapat mengkombinasikan dua unsur budaya yang berbeda. Proses akulturasi dalam mengkombinasi keberagaman dari dua budaya tersebut membutuhkan waktu berbulan-bulan dalam beradaptasi dan diperlukan adanya seleksi dengan pertimbangan yang matang dari setiap karyawan PT NHM, untuk dapat berproses, memahami, mempelajari, membuat komitmen penuh dan menghargai perbedaan budaya di dalam PT NHM.

Dampak positif yang dihasilkan diantaranya terjadi perubahan cara pandang individu mengenai perbedaan budaya, cara berpikir lebih global/luas, melalui keberagaman juga setiap individu mengetahui cara berkomunikasi yang baik dan cara bersosialisasi yang baik. Setiap orang yang bekerja di PT NHM merupakan keluarga dan dari kekeluargaan tersebut dapat membentuk sebuah tim yang solid yang memiliki satu tujuan yang sama. Hasil dari penelitian ini ditemukan adanya hambatan dan tantangan dalam manajemen keberagaman melalui akulturasi, yaitu kurangnya informasi yang disosialisasikan sehingga harus ada sosialisasi, namun jika muncul adanya hambatan dan tantangan setiap karyawan perusahaan dapat mengatasi hambatan dan tantangan tersebut.

Saran dari penelitian ini, dapat menjadi manfaat bagi Manajemen PT $\mathrm{NHM}$ dalam mengembangkan komunikasi antarbudaya, menjadi pengembangan ilmu pengetahuan dalam bidang sumber daya manusia khususnya manajemen keberagaman melalui akulturasi budaya kerja ekspatriat dan lokal, melalui penelitian ini juga dapat menjadi rujukan ketika suatu organisasi melakukan perubahan dalam lingkungan kerja dengan membangun manajemen keberagaman melalui proses akulturasi.

\section{UCAPAN TERIMAKASIH}

Peneliti mengucapkan terima kasih kepada Tuhan yang Maha Esa, 
Oktadwilaras Anugerah Putri Papuling, Agus Sugiarto | Membangun Manajemen Keberagaman Melalui Akulturasi Budaya Kerja Karyawan Ekspatriat Dan Karyawan Lokal

Universitas Kristen Satya Wacana, Fakultas Ekonomika dan Bisnis, dan PT NHM yang sudah membantu peneliti dalam memberikan data maupun informasi dalam menyelesaikan penelitian ini.

\section{DAFTAR PUSTAKA}

Abdul, M. M., \& Budhwar, P. (2013). Cultural intelligence as a predictor of expatriate adjustment and performance in Malaysia. Journal of World Business, 48 (2), 222231.

https://doi.org/10.1016/j.jwb.2012. 07.006

Ahmad, S. B. (2012). Pengantar Antropologi. CV Pustaka Setia.

Anakotta, R., Alman, A., \& Solehun, S. (2019). Akulturasi Masyarakat Lokal Dan Pendatang Di Papua Barat. Jurnal Antropologi: Isu-Isu Sosial Budaya, 21(1), 29. https://doi.org/10.25077/jantro.v21. n1.p29-37.2019

Ayu, I. W. (2015). Gambaran Dinamika Culture Shock Pada Mahasiswa Thailand di IAIN Tulungagung (Sebuah Studi Kasus pada Mahasiswa Asing dari Thailand yang Menempuh Pendidikan di IAIN Tulungagung). IAIN Tulungagung Press.

Berry, J. W. (2005). Acculturation: Living successfully in two cultures. International Journal of Intercultural Relations, 29(6), 697712.

https://doi.org/10.1016/j.ijintrel.200 5.07 .013

Corbin, J., \& Strauss, A. (2008). Basics of Qualitative Research: Techniques and Procedures for
Developing Grounded Theory (3rd ed.). Thousand Oaks, CA: Sage.

Deddy, M., \& Jalaludin, R. (2006). Komunikasi Antar Budaya Panduan Berkomunikasi dengan Orang-Orang Berbeda Budaya. PT Remaja Rosdakarya.

Fajar, M. (2009). IImu Komunikasi:Teori dan Praktik. Graha IImu Cetakan Pertama.

Farmanesh, P., Vehbi, A., Zargar, P., Sousan, A., \& Bhatti, F. (2020). Is there always a positive relationship between workplace diversity and organizational performance, or does diversity fatigue imply a suppressing effect. The South East European Journal of Economics and Business, 15(1), 14-26. https://doi.org/10.2478/jeb2020-0002

Fathonah, U. (2017). Akulturasi Psikologis Mahasiswa Asing di Indonesia (Studi Fenomenologi Mahasiswa Thailand di IAIN Tulungagung). IAIN.

Firmansyah, R. (2016). Konsep Dasar Asimilasi dan Akulturasi dalam Pembelajaran Budaya. Tidak TKonsep Dasar ASIMILASI \& AKULTURASI Dalam Pembelajaran BUDAYA, December.

https://www.researchgate.net/publi cation/311718551_Konsep_Dasar ASIMILASI_AKULTURASI_dala m_Pembelajaran_BUDAYA

Fitriana, A. D., Agama, I., Negeri, I., \& Parepare, I. (2018). Pengaruh Akulturasi Dalam Proses Interaksi Antarbudaya Terhadap Kesadaran Budaya Berbahasa Daerah Jurnal IImu Sosial dan Humaniora | 560 
Oktadwilaras Anugerah Putri Papuling, Agus Sugiarto | Membangun Manajemen Keberagaman Melalui Akulturasi Budaya Kerja Karyawan Ekspatriat Dan Karyawan Lokal

Setempat Bagi Mahasiswa Rantau. KOMUNIDA: Media Komunikasi Dan Dakwah, 8(1), 40-50.

Flory, J. A., Leibbrandt, A., Rott, C., \& Stoddard, O. (2021). Increasing Workplace Diversity Evidence from a Recruiting Experiment at a Fortune 500 Company. Journal of Human Resources, 56(1), 73-92. https://doi.org/10.3368/jhr.56.1.05 18-9489R1

Han, E. S., \& goleman, daniel; boyatzis, Richard; Mckee, A. (2019). Komunikasi A. Journal of Chemical Information and Modeling, 53(9), 1689-1699.

Hasanuddin, H., Surati, S., \& Ramly, A. T. (2020). Pengaruh Budaya Organisasi, Kompensasi, Dan lingkungan Kerja Terhadap Kinerja Pegawai Dengan Kepuasaan Kerja Sebagai Variabel Intervening (Kantor Bappeda Kabupaten Bima NTB). Jurnal Manajemen, 11(2), 253. https://doi.org/10.32832/jmuika.v11i2.3365

Hendriawan. (2014). Pengaruh Peran Ekspatriate Terhadap Kinerja Perusahaan Industri Telekomunikasi di Indonesia Berdasarkan Alih Pengetahuan, Kapabilitas Perusahaan dan Budaya Perusahaan. Universitas Indonesia.

Hurst, R. R., \& Pattath, P. (2019). Organizational identity in acculturation in cross-border acquisitions: Implications for HRD practitioners in global M\&A. Human Resource Development International, 22(1), 44-67. https://doi.org/10.1080/13678868. 2018.1488487

Koentjaraningrat. (1994). Kebudayaan Mentalitas Dan Pembangunan. Gramedia Pustaka Utama.

Koetjaraningrat. (2005). Pengantar IImu Antropologi. PT. Rineka Cipta.

Kraus, S., Schleich, M., Tröster, A., \& Roig-Tierno, N. (2019). Cultural diversity in large enterprises: A qualitative analysis from the Alpine Rhine Valley. Journal of Promotion Management, 25(5), 640-663. https://doi.org/10.1080/10496491. 2019.1585570

Lauer, R. H. (2001). Perspektif tentang perubahan sosial. In Perspektif tentang perubahan sosial. Rineka Cipta.

Marx, A., \& Westood, M. (1999). Optimising Condition for Learning Sociocultural Competence for Succes. International Journal of Intercultural Relation.

Mu, A. (2019). Akulturasi. Journal of Chemical Information and Modeling, 53(9), 1689-1699.

Muzakkir, \& Fadhlain, S. (2019). Konsep akulturasi budaya masyarakat tionghoa ditinjau dari komunikasi antar budaya (studi kasus etnis tionghoa di wilayah barat selatan aceh). Jurnal IImu Komunikasi, 8(2), 258-274.

Ng, E. S., \& Sears, G. J. (2020). Walking the talk on diversity: CEO beliefs, moral values, and the implementation of workplace diversity practices. Journal of Business Ethics, 164(3), 437-450. https://doi.org/10.1007/s10551018-4051-7

Jurnal IImu Sosial dan Humaniora | 561 
Nguyen, T., \& Velayutham, S. (2018). Everyday inter-ethnic tensions and discomfort in a culturally diverse Australian workplace. Social Identities, 24(6), 779-794. https://doi.org/10.1080/13504630. 2017.1329655

Piperopoulos, P. (2010). Qualitative Research in SMEs and Entrepreneurship: A Literature Review of Case Study Research. International Journal of Economics and Business Research, 2 (6), 494-510.

Pourjam, A. (2020). Cultural Diversity Management and Organizational Outcome in Tourism Businesses Workplace: Spirituality as a mediator. International Journal of Tourism \& Spirituality, 4(2).

Rakhmat, D. dkk. (2009). Komunikasi Antar Budaya. PT Remaja Rosdakarya.

Rasool, A., Khatir, G., \& Nadir, N. S. (2018). Diversity And Its Impact On Employee Satisfaction And Performance. CLEAR International Journal of Research in Commerce \& Management, 9(7).

Singha, S., \& Sivarethinamohan, R. (2021). Diversity Climate of Organization: A Sustainable Way in India. Ilkogretim Online, 20(4). https://doi.org/10.17051/ilkonline.2 021.04.292

Siregar, R. A., \& Perdhana, M. S. (2018). Tahapan penyesuaian lintas budaya pada ekspatriat di kota semarang. Diponegoro Journal Of Management, 7, 1-6.

Somovar, Larry A,\& Richard E Porter, E. R. M. D. (2010). Komunikasi
Lintas Budaya, Salemba Humanika. Gudykunst, B.

Taras, V., Rowney, J., \& Steel, P. (2013). Work-related acculturation: Change in individual work-related cultural values following immigration. International Journal of Human Resource Management, 24(1), 130-151. https://doi.org/10.1080/09585192. 2012.672446

Wanda Wijaya, \& Eddy Madiono Sutanto. (2014). Human Relations Tenaga Keria Asing dan Tenaga Kerja Lokal di PT Gramitrama Jaya Steel. AGORA, 2(2), 8.

Wentling, R. M., \& Palma-Rivas, N. (1997). Diversity in the Workforce: A Literature Review. Diversity in the Workforce Series Report\# 1.

Yunus, R. (2013). Transformasi NilaiNilai Budaya Lokal Sebagai Upaya Pembangunan Karakter Bangsa (Penelitian Studi Kasus Budaya Huyula Di Kota Gorontalo). Jurnal Penelitian Pendidikan, 14(1), 6577. 